Cova, Massimo.

Profesor de la Facultad de Bellas Artes de la Universidad de Barcelona, Departamento de Artes Visuales y Diseño, Sección de Producción de Arte Contemporáneo.

\title{
Arte contemporáneo y señales visuales de la cotidianidad como paradigma de modelos globales de vida y de pensamiento.
}

\section{Contemporary art and visual signals from daily life as a paradigm of global models of living and thinking.}

\author{
TIPO DE TRABAJO: \\ Comunicación. \\ PALABRAS CLAVE: \\ Arte contemporáneo, Cotidianidad, Señales visuales, Identidad
}

KEY WORDS:

Contemporary art, Daily living, Visual signals, Identity.

\section{RESUMEN.}

Nuestra propuesta consiste en presentar un proyecto artístico personal y analizar su vinculación con obras de reconocidos artistas contemporáneos que adoptan, como referentes formales y conceptuales, unas señales visuales espontáneas presentes en los entornos cotidianos. Rastros efímeros y transitorios generados por los comportamientos y por las interacciones de las personas, que pueden ser representativos de modelos de vida y de pensamiento en la era de la globalidad. Las obras propuestas (tanto las personales como las de referencia) formalizan y reconfiguran en el lenguaje propio del arte, unas huellas y unos indicios visuales que no pertenecen en su origen al territorio artístico. Marcas, restos o vestigios relacionados con aspectos de las complejas consecuencias de la internacionalización económica y cultural así como del desarrollo y de la expansión de las nuevas tecnologías o de modelos de comportamiento como fundamento de identidades individuales y colectivas. Nuestro proyecto se compone de series de obras de diversos formatos y técnicas, realizadas a partir de nuestra experiencia en relación con estos signos cotidianos e inspiradas en referentes artísticos de reconocido prestigio y legitimidad internacional. El proyecto nace en 2009 con la serie titulada Alter ludus. De la experiencia docente a la experimentación artística, una reflexión sobre las manifestaciones visuales espontáneas del colectivo adolescente en el ámbito escolar, que se hacen paradigma de comportamientos y de dinámicas del mundo adulto. Siguen otras series como la titulada En directo. Rastros pictóricos de información, con la que dirigimos una mirada crítica a los límites de la información electrónica a través de la trascendencia de la complejidad pictórica; o Don't touch!, que reflexiona sobre normas y convenciones, inhibiciones i tabúes, hasta las últimas producciones centradas en tendencias del pensamiento contemporáneo relativo a la ciencia, a la tecnología y a la controvertida relación entre la cultura y la historia. 


\section{ABSTRACT.}

Our proposal consists of presenting a personal art project and analysing its relationship with works by renowned contemporary artists that adopt a number of spontaneous visual signals present in daily settings as formal and conceptual references. Fleeting and transitory traces produced by people's behaviours and interactions which can be representative of models of living and thinking in the global era. The proposed works (both the personal pieces and the references) formalise and reconfigure into the language of art a number of footprints and visual indications which do not owe their origin to the artistic terrain. Marks, remains and vestiges related to aspects of the complex consequences of economic and cultural internationalisation and the creep of new technologies and models of behaviour as a cornerstone of individual and collective identities. Our project comprises a series of works of various formats and techniques that build on our experience in relation to these daily signs and are inspired by artistic references of recognised standing and international legitimacy. The project began in 2009 with the series entitled Alter Ludus - From Teaching Experience to Artistic Experimentation, a reflection on the spontaneous visual manifestations of adolescents in the school environment which form a paradigm of behaviours and dynamics of the adult world. Other series were to follow, such as Live: Pictorial Traces of Information, where we took a critical look at the limits of electronic information through the importance of pictorial complexity, and Don't Touch!, a reflection on norms and conventions, inhibitions and taboos, through to the latest productions centring on trends in contemporary thought regarding science, technology and the controversial relationship between culture and history. 